\title{
Christian Magicians, Jewish Magical Idioms, and the Shared Magical Culture of
}

\author{
Late Antiquity ${ }^{*}$
}

Ra'anan Boustan and Joseph E. Sanzo

\section{Introduction}

Some time in the late-fifth or early-sixth-century C.E., a ritual practitioner-operating in the environs of Oxyrhynchus, Egypt — created a protective amulet that reads, "Hôr, Hôr, Phôr, Elôei, Adônai, Iaô, Sabaôth, Michaêl, Jesus Christ. Help us and this house. Amen” ( $\Omega \rho, \Omega \rho$,

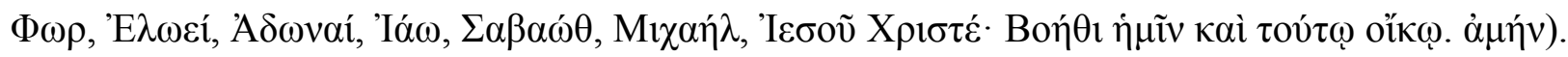
Each of the names used in the first part of this amulet, known as P.Oxy. VIII 1152 (=PGM P6a), is familiar from other ritual objects from late antiquity (approx. fourth to seventh centuries C.E.). ${ }^{1}$ But the juxtaposition of these divine names on a single amulet presents us with a puzzle: Did the ritual expert who created this artifact or his client perceive there to be a difference, tension, or even contradiction between Jesus Christ and the other names listed? Or, alternatively, would they have conceptualized all of these names as belonging equally within what they would have thought of as the "Christian tradition" or some other tradition?

\footnotetext{
* The authors would like to thank Adam Becker, Henry Gruber, Chrysi Kotsifou, Yonatan Moss, Shira Lander, Eirini Panou, Tamar Pataridze, and the anonymous HTR reviewers for their useful comments on this article. Of course, the authors are responsible for any remaining infelicities of style or errors of substance. Joseph E. Sanzo would also like to thank the faculty and staff of the Center for the Study of Christianity at the Hebrew University of Jerusalem, especially Professor Brouria Bitton-Ashkelony, for their support during the 2013-2015 academic years. Abbreviations: PGM = Karl Preisendanz, ed., Papyri Graecae Magicae: Die griechischen Zauberpapyri (rev. ed. A. Henrichs; 2 vols.; Stuttgart: K G Saur Verlag Gmbh \& Co, 1973); ACM = Marvin Meyer and Richard Smith eds., Ancient Christian Magic: Coptic Texts of Ritual Power (Princeton, N.J.: Princeton University Press, 1999). For all other abbreviations of artifacts, see the Duke University Checklist of editions of Greek, Latin, Demotic, and Coptic Papyri, Ostraca and Tablets (http://library.duke.edu/rubenstein/scriptorium/papyrus/texts/clist.html). Translations haven been taken from ACM unless otherwise stated.

${ }^{1}$ In addition to the numerous amulets and spells that refer to Jesus and the archangel Michael, a group of amulets that invoke the "Artemisian scorpion" also utilize Hôr, Hôr, Phôr, Elôei, Adônai, Iaô, Sabaôth in various configurations (P.Oxy. VII 1060; P.Oxy. XVI 2061; P.Oxy. XVI 2062; P.Oxy. XVI 2063; and P.Oslo I.5). For a discussion of these amulets as part of a larger treatment of the "scorpion" motif in late antique Egypt, see Marcus Todd, "The Scorpion in Graeco-Roman Egypt," JEA 25 (1939) 55-61.
} 
When confronted by the presence of names or motifs from seemingly different religious traditions on a single artifact, scholars of ancient magic have tended, often without explicit methodological justification, to classify each of those elements in terms of its "original" linguistic or cultural context. ${ }^{2}$ In 1911, Arthur Hunt referred to P.Oxy. VIII 1152 as “a short incantation containing magical, Jewish, and Christian elements." ${ }^{, 3}$ This deep scholarly reflex continues to inform contemporary work on amulets and other ritual artifacts. Thus, the checklist of Greek ritual artifacts containing Christian elements recently compiled by Theodore de Bruyn and Jitse Dijkstra, while considerably more cautious in its application of categories of religious identification, still characterize this particular amulet as a prime example of the juxtaposition of "Christian" elements with "Graeco-Egyptian and Jewish powers." Certainly, the scholarly practice of emphasizing the diverse origins of elements present in a given text, genre, or corpus highlights the degree to which practitioners serving various religious communities in the late antique Mediterranean and Near East participated in a shared magical culture. ${ }^{5}$ But, in our view, the scholarly predilection to label isolated elements and to formulate abstract rules governing the limits of what a practitioner from a given religious community might do when writing an amulet builds unwarranted definitions into the very phenomena that a scholar has set out to study. ${ }^{6}$

We argue in this essay that the task of interpreting the apparent juxtaposition of seemingly diverse elements on magical artifacts must consider the full spectrum of strategies that

\footnotetext{
${ }^{2}$ We deploy the term "magic" in full recognition of the problems associated with its use as an independent lexeme. For our purposes, the term is intended merely as a convenient way to talk about a loose body of artifacts and texts, but without prejudging their relationship to other spheres of social existence (e.g., religion and science). For an overview of these issues within the study of early Christianity, see David Aune, "'Magic' in Early Christianity and Its Ancient Mediterranean Context: A Survey of Some Recent Scholarship,” ASE 24 (2007) 229-94.

3 Arthur S. Hunt, ed., "1152. Christian Amulet," in The Oxyrhynchus Papyri (ed. Arthur S. Hunt; vol. 8; London: Egypt Exploration Society, 1911) 253.

4 Theodore S. de Bruyn and Jitse H. F. Dijkstra "Greek Amulets and Formularies from Egypt Containing Christian Elements: A Checklist of Papyri, Parchments, Ostraka, and Tablets,” BASP 48 (2011) 163-216, at 181-82.

${ }^{5}$ See Shaul Shaked, "Jesus in the Magic Bowls: Apropos Dan Levene's '...and by the name of Jesus...,", JSQ 6 (1999) 309-19, at 315-16.

${ }^{6}$ On this point, see already Joseph E. Sanzo, Scriptural Incipits on Amulets from Late Antique Egypt: Text, Typology, and Theory (Tübingen: Mohr Siebeck, 2014) 10-14.
} 
ritual specialists used to negotiate religious similarity and difference. In particular, we propose an approach to such materials that emphasizes the dialectical processes of indigenization and exoticization that were often at work within late antique magical discourse. We believe that this approach will better enable us to understand how difference was alternatively marked out, effaced, or simply ignored by ritual practitioners as they pursued their immediate, local aims. At the same time, this approach highlights the perilous gap that too often exists between modern scholarly conceptions of religious difference and the ancient categories that in practice shaped the contours of a given religious tradition.

Toward this end, our paper considers how best to describe, categorize, and analyze the presence of so-called Jewish elements in Christian magical materials from late antiquity. This task demands that we neither ignore nor reify the distinctions between the Jewish and Christian magical traditions. The apparent juxtaposition of divine names, mythic figures, historiolae, authoritative personages, and so on, in magical materials of all religious stripes often merely reflects the pragmatic bent of ritual experts in late antiquity; in most instances where modern scholars perceive religious difference among various elements in a single artifact, ancient practitioners did not overtly mark this juxtaposition rhetorically, graphically, or otherwise. At the same time, some ritual artifacts do appear to capitalize on the perceived exoticism of a given element, translating its foreignness into authority or ritual power.

This paper lies at the intersection of the academic fields of ancient magic and early Jewish-Christian relations, and we hope will contribute to both. For the scholar of ancient magic, this paper offers a new approach to dealing with the apparent juxtaposition of idioms from seemingly different religious traditions. We argue that the field should move beyond simply labeling elements based on their presumed historical or linguistic origins to consider the 
fluctuating nature of religious idioms and communal boundaries. For those primarily interested in early Jewish-Christian relations, this paper provides a window into how boundaries between Jews and Christians were drawn and understood in the "lived" contexts of late antique Christianity. ${ }^{7}$ Most studies of the dynamic interaction between formative Judaism and Christianity—whether traditional or revisionist—focus on the writings of rabbinic and patristic elites and, therefore, tend to observe this process from above, as it were. ${ }^{8}$ In our judgment, scholars have yet to consider adequately the implications of amulets and other ritual objects for the study of Jewish-Christian relations in large measure because of the prevailing assumption that the eclectic and even inclusive strategies that ritual practitioners pursued were fundamentally at odds with the exclusionary discourse that characterized efforts at religious differentiation.

By contrast, we demonstrate that the concerns of ritual efficacy and boundary demarcation could be mutually reinforcing and, on occasion, could overlap in ways that eclipsed the distinctions between Jews and Christians that ecclesiastical elites frequently promoted and that contemporary historians of religion have so often assumed. We analyze a series of ritual artifacts that illustrate the range of uses to which Christian practitioners put seemingly Jewish

\footnotetext{
${ }^{7}$ We build upon the work of those scholars who have stressed the interpenetration of Jewish and Christian ideas and expressive forms throughout late antiquity, a trend exemplified by Peter Schäfer, The Jewish Jesus: How Christianity and Judaism Shaped Each Other (Princeton, N.J.: Princeton University Press, 2012); Adam H. Becker and Annette Yoshiko Reed, eds., The Ways that Never Parted: Jews and Christians in Late Antiquity and the Early Middle Ages (Minneapolis: Fortress Press, 2007; repr. Tübingen: Mohr Siebeck, 2003); and Daniel Boyarin, Border Lines: The Partition of Judaeo-Christianity (Philadelphia: University of Pennsylvania Press, 2004).

${ }^{8}$ Even those studies that draw heavily on archaeological and art historical evidence to explore the fluidity of Christian and Jewish identities in late antiquity rarely integrate "magical" sources into their account. A notable exception is the excellent study by Éric Rebillard, Christians and their Many Identities in Late Antiquity, North Africa, 200-450 CE (Ithaca, N.Y.: Cornell University Press, 2012) 71-75, though here, too, the evidence for socalled "magical" practice is primarily filtered through the writings of Augustine and other episcopal elites. It should be noted that, by contrasting "magical" discourse and "elite" discourse, we by no means intend to downplay the important role of local elites (e.g., monks and other scribes) in the manufacturing or use of amulets and the like. Instead, our point is to emphasize the great extent to which patristic authors (and rabbis) have shaped scholarly conceptions of what constituted appropriate "Christian" (or "Jewish") language in late antiquity. For the role of monks and other local specialists in the creation of magical artifacts, see especially David Frankfurter, "Dynamics of Ritual Expertise in Antiquity and Beyond: Towards a New Taxonomy of 'Magicians,"' in Magic and Ritual in the Ancient World (ed. Paul A. Mirecki and Marvin W. Meyer; Leiden: Brill, 2002) 159-78, at 167-70; David Brakke, Demons and the Making of the Monk (Cambridge: Harvard University Press, 2006) 226-39.
} 
elements within their spells. The texts considered here were produced in Egypt and Syria from approximately the fourth to seventh centuries C.E. and were written in a range of languages (Greek, Coptic, and Syriac). Each of these texts offers important clues for determining the various approaches Christian practitioners might take to ostensibly Jewish elements. At the same time, the diverse contexts in which these artifacts were created allow us to consider how specific regional and historical circumstances shaped the relationship between the language of magic and the language of religious self-identification.

\section{The Function of the Exotic in Ancient Mediterranean Magic}

Our investigation into what late antique ritual specialists were actually doing when they clustered elements from seemingly different religious traditions in their amulets and spells requires us to grapple with a series of questions: Do symbols and idioms that become closely linked with a given culture or group, often on the basis of their putative origins, retain such associations and identifications when applied by an individual from another group? If so, under what conditions do those associations and identifications persist and for how long?

Scholars of ancient magic have argued that scribes and practitioners studded their ritual scripts with elements that they considered exotic in an effort to lend them authority as well as to enhance their "coefficient of weirdness." Among the various magical corpora from late antiquity, the so-called Greek and Demotic Magical Papyri appear to be particularly susceptible

\footnotetext{
${ }^{9}$ On the "coefficient of weirdness," see especially Bronisław Malinowski, Coral Gardens and the Their Magic: A Study of the Methods of Tilling the Soil and of Agricultural Rites in the Trobriand Islands (2 vols.; London: G. Allen \& Unwin, 1935) 2:218-25. For the applicability of the "coefficient of weirdness" to objects from antiquity, see David Frankfurter, "Fetus Magic and Sorcery Fears in Roman Egypt," GRBS 46 (2006) 37-62, at 1519; Andrew T. Wilburn, Materia Magica: The Archaeology of Magic in Roman Egypt, Cyprus, and Spain (Ann Arbor, Mich.: The University of Michigan Press, 2012) 12-13.
} 
to an interpretation that stresses their creators' strategic use of exotic elements. ${ }^{10}$ Thus, for example, Morton Smith argued influentially that many of the "Pagan" creators of the Greek Magical Papyri peppered their spells with foreign-sounding "Jewish" or "Hebrew" elements in order to supercharge them with an air of power and authority. ${ }^{11}$

But this approach to the presence of "Jewish" elements in non-Jewish magic is tacitly predicated upon a narrow conception of the "exotic" and, consequently, obfuscates the manifold ways ancient practitioners might have approached these idioms and symbols. To this end, there is much to be gained by considering how historians and social theorists more generally have come to think about the circulation of "exotic" elements across cultural and social boundaries and their potential ideological functions in their new settings.

Postcolonial theorists have found significant analytical value in the notion of the "exotic" (and its cognates) as a lens for understanding the functions that the cultural, ethnic, racial, or religious Other has served within colonialist discourses. ${ }^{12}$ Thus, in her work on European travel literature, Mary-Louise Pratt has detailed how representations of non-Europeans helped to produce European knowledge about previously unknown cultures and regions, while also

\footnotetext{
${ }^{10}$ See, for instance, William Brashear, "The Greek Magical Papyri: An Introduction and Survey; Annotated Bibliography (1928-1994)," in ANRW II.18.5 (ed. Wolfgang Haase; Berlin: Walter de Gruyter \& Co., 1995) 33803684 , at $3422-29$.

${ }^{11}$ See especially Morton Smith, "The Jewish Elements in the Magical Papyri," in Studies in the Cult of Yahweh (ed. Shaye J. D. Cohen; 2 vols.; Leiden: Brill, 1996) 2:242-56. See also Arthur Darby Nock, "Jewish Symbols in the Greco-Roman World by Erwin R. Goodenough," Gnomon 27 (1955) 558-72, at 570. More recently, Giancarlo Lacerenza has claimed that the use of divine or angelic names like "Sona'el," "Abraoth," and "Iao" on an amulet from the Christian catacombs of Naples "clearly displays Jewish connotations" ("Jewish Magicians and Christian Clients in Late Antiquity: The Testimony of Amulets and Inscriptions," in What Athens has to do with Jerusalem: Essays on Classical, Jewish, and Early Christian Archaeology in Honor of Gideon Foerster [ed. Leonard V. Rutgers; Leuven: Peeters, 2002] 396-419, at 411). Lacerenza, however, does not provide any evidence suggesting that the practitioner who authored this amulet viewed these elements — which, to be sure, have Semitic origins - as "Jewish."

${ }^{12}$ Edward Said, Orientalism (New York: Pantheon, 1978); see also Homi K. Bhabha, The Location of Culture (London: Routledge, 1994).
} 
justifying colonial practices of domination. ${ }^{13}$ Building upon this intellectual tradition, scholars of religion like Timothy Fitzgerald and Randall Styers have detailed how the emergent scholarly categories "religion" and "magic" were framed in relation to exoticism and otherness and, consequently, participated in the construction of "modern" ideology and concomitant colonial projects..$^{14}$

Scholars of the pre-modern world, especially in art history, have likewise deployed the concept of the exotic to capture how emperors, elites, and specialists appropriated signs linked to the cultural or religious Other. One recent trend within this line of scholarship is to draw a distinction between the "exotic" and the merely "foreign." In her study of the display of high prestige artifacts at the imperial court in the medieval Byzantine Empire, art historian Alicia Walker defines the exotic as "a fluid, generative process through which cultural difference is negotiated and both foreign and indigenous identities are defined." ${ }^{15}$ By extension, exotic elements are "active agents of meaning" and "represent powerful gestures aimed at the resolution of the curiosities, pleasures, and anxieties spurred by encounters with cultural Others.." ${ }^{16}$ In contrast to the notion of the "exotic," Walker uses the term "foreign" more generally to denote elements that come from outside the society under investigation, "but can still be associated with a specific external cultural, historical, and/or geographical group." ${ }^{17}$ Alongside these two terms, 2008) 3

${ }^{13}$ Mary-Louise Pratt, Imperial Eyes: Travel Writing and Transculturation (2nd ed.; London: Routledge,

${ }^{14}$ Timothy Fitzgerald, The Ideology of Religious Studies (New York: Oxford University Press, 2000) 3; Randall Styers, Making Magic: Religion, Magic, \& Science in the Modern World (Oxford: Oxford University Press, 2004) 8-14. The emphasis on the imposition from the outside is not to deny the possibility of "stereotype appropriation," by which a subaltern group embraces its exoticized persona. For discussion of this phenomenon as it relates to ritual specialization in late antique Egypt, see David Frankfurter, Religion in Roman Egypt: Assimilation and Resistance (Princeton, N.J.: Princeton University Press, 1998) 224-37; Jacco Dieleman, Priests, Tongues, and Rites: The London-Leiden Magical Manuscripts and Translation in Egyptian Ritual (100-300 CE) (Leiden: Brill, 2005) 9-10, 287.

${ }^{15}$ Alicia Walker, The Emperor and the World: Exotic Elements and the Imaging of Middle Byzantine Imperial Power, Ninth to Thirteenth Centuries C.E. (Cambridge: Cambridge University Press, 2012) xx.

${ }^{16}$ Ibid.

${ }^{17}$ Ibid. 
Walker uses "hybrid" to refer to an object in which foreign and indigenous elements are consciously juxtaposed, with meaning deriving from "the friction between disparate parts.",18 Walker applies this theoretical framework to a series of case studies in order to show how elements from Sasanian, Islamic, and Chinese cultures were incorporated into, but left visible within Byzantine imperial objects (e.g., textiles and ivory boxes) and architectural structures (e.g., buildings within the palace complex). ${ }^{19}$ For Walker, such exotic elements were intentionally deployed "to project a cosmopolitan concept of imperial authority." ${ }^{20}$ Crucially for our purposes, Walker's typology points to the manifold ideological functions that the juxtaposition of elements from seemingly different traditions might serve. Indeed, "exoticism" is itself dynamic and represents only one possible horizon of appropriation and usage.

The social complexities that underlie analytical categories such as "foreign," "exotic," and "hybrid" are also inextricably entwined with the rubric "syncretism," which has been the primary term used to characterize and explain instances of apparent juxtaposition in the study of ancient magic. ${ }^{21}$ Of course, historians of religion have long recognized the theological baggage associated with the term syncretism. Indeed, this rubric has often been used, especially within the study of religion, as a derogatory term to denote those processes whereby originally "pure"

\footnotetext{
18 Ibid.

${ }^{19}$ For a similar argument, see also Andrew W. Collins, “The Royal Costume and Insignia of Alexander the Great," AJP 133 (2012) 371-402.

${ }^{20}$ Walker, Emperor and the World, xiii.

21 The terms "syncretism" and "syncretistic" are frequently invoked in scholarship on ancient magic. See, e.g., the use of this term as analytical categories for discussing "national" elements and influences in the now classic Campbell Bonner, Studies in Magical Amulets (Ann Arbor, Mich.: University of Michigan Press, 1950) 22-42. For more recent use, see the influential statements in Hans Dieter Betz, "Introduction to the Greek Magical Papyri," in The Greek Magical Papyri in Translation Including the Demotic Spells (ed. Hans Dieter Betz; Chicago: University of Chicago Press, 1986) xli-lii, at xlv-xlvi; Brashear, "The Greek Magical Papyri," 3422. In the context of the study of the New Testament, see Clinton E. Arnold, The Colossian Syncretism: The Interface between Christianity and Folk Belief at Colossae (Grand Rapids, Mich.: Baker Books, 1996) 11-31.
} 
religious traditions become adulterated and thus corrupted and even degenerate. ${ }^{22}$ Some have, therefore, called for the elimination of the term syncretism completely from the conceptual vocabulary of the field. ${ }^{23}$

More recently, however, David Frankfurter has attempted to revive syncretism as an analytical tool within the study of religion. ${ }^{24}$ Frankfurter's revised version of syncretism highlights the complex ways late antique ritual experts engaged with "new" and "old" elements, resulting in the creation of novel and even hybrid religious traditions. ${ }^{25}$ This model of syncretism is especially useful for describing the creative agency of ritual experts at specific moments of cultural transition as well as for tracing shifts in religious idioms over the longue durée. ${ }^{26}$ Indeed, as our analysis below suggests, at least some practitioners and clients in antiquity seem to have capitalized on the authority or power generated through their mastery over an eclectic assortment of materials drawn from a range of authoritative traditions that they and, crucially, their clients would have seen as distinct or at least distinguishable. ${ }^{27}$

Nevertheless, the dynamic of agency endemic to this approach to the category syncretism is temporally contingent and thus limited in its heuristic utility. As Michael Pye has shown, syncretism tends toward "resolution," whether in the form of "assimilation" (i.e., weaker

\footnotetext{
${ }^{22}$ Rosalind Shaw and Charles Stewart, "Introduction: Problematizing Syncretism," in Syncretism/AntiSyncretism: The Politics of Religious Synthesis (ed. Charles Stewart and Rosalind Shaw; London: Routledge, 1994) $1-26$.

${ }^{23}$ Robert Baird, for instance, famously included syncretism in a chapter titled, "Some Inadequate Categories" in his Category Formation and the History of Religions (Hague: Mouton, 1971) 126-54. For various perspectives on the heuristic utility of the category syncretism, see the essays in William Cassidy, ed., "Retrofitting Syncretism?" Historical Reflections 27 (2001) 365-507.

${ }^{24}$ David Frankfurter, "Syncretism and the Holy Man in Late Antique Egypt," JECS 11 (2003) 339-85.

${ }^{25}$ Concerning "Christian magic," Lacerenza likewise states, "[t]he difficulty in finding 'purely Christian' magic is due to the fact that Christian magicians seem to have been particularly interested in appropriating foreign spiritual codes and techniques" (Lacerenza, "Jewish Magicians and Christian Clients," 405).

${ }^{26}$ See also Shaw and Stewart, "Introduction"; Michael Pye, "Syncretism versus Synthesis," MTSR 6 (1994) 217-29; Siv Ellen Kraft, “"To Mix or Not to Mix': Syncretism/Anti-Syncretism in the History of Theosophy," Numen 49 (2002) 142-77.

${ }^{27}$ On the relationship of magic to the institutionalized and authoritative religious traditions of the ancient world, see David Frankfurter, "The Great, the Little, and the Authoritative Tradition in Magic of the Ancient World," ARG 17 (forthcoming 2015).
} 
elements are absorbed into the dominant tradition), "dissolution" (i.e., "the reassertion of the separate identity or divergent meaning of disparate elements which are consequently drawn apart"), or "synthesis" (i.e., a new religious tradition). ${ }^{28}$

Something analogous to these dimensions of resolution (especially "assimilation") seems to be at work in the vast majority of alleged cases of Jewish "exoticism" in the Greek Magical Papyri. Thus, most scholars would follow Gideon Bohak's cautious, but reasonable assessment regarding the limited presence of Hebrew and other Jewish elements in non-Jewish magic. ${ }^{29}$ In his view, given the length of time these elements circulated within Egypt, the non-Jewish Egyptian practitioners who thought of Adônai or Iaô Sabaôth, for instance, as specifically or exclusively Jewish were in the minority. And, as Lynn LiDonnici has shown, the instances in which the papyri demonstrate an awareness of "Jewish" or "Hebraic" elements are incredibly rare and in fact often reflect the work of Jewish practitioners - albeit those out of step with the boundary keepers of Judaism. ${ }^{30}$

These historical and social considerations in turn hint at an important principle that ought to inform evaluations of apparent juxtaposition: inherent in the notion of an exotic element—and, by extension, syncretism - is an acute awareness of difference and even otherness. As art historian Jonathan Hay has noted, exoticism is best seen as "a mechanism regulating the fear and desire associated with awareness of the foreign." 31 Accordingly, it follows that exotic elements are primarily associated with moments of transition and initial infiltration (i.e., before syncretism

${ }_{28}^{28}$ Pye, "Syncretism versus Synthesis," 222.

${ }^{29}$ See especially Gideon Bohak, Ancient Jewish Magic: A History (Cambridge: Cambridge University Press, 2008) 196-209; idem, "Hebrew, Hebrew Everywhere? Notes on the Interpretation of Voces Magicae," in Prayer, Magic, and the Stars in the Ancient and Late Antique World (ed. Scott Noegel, Joel Walker, and Brannon M. Wheeler; University Park, Pa.: Pennsylvania State University Press, 2003) 69-82; also John Gager, Moses in Greco-Roman Paganism (New York: Abingdon Press, 1972) 135-36.

${ }^{30}$ Lynn LiDonnici, “'According to the Jews:' Identified (and Identifying) 'Jewish' Elements in the Greek Magical Papyri," in Heavenly Tablets: Interpretation, Identity and Tradition in Ancient Judaism (ed. Lynn LiDonnici and Andrea Lieber; Leiden: Brill, 2007) 87-108.

31 Jonathan Hay, "Editorial: Toward a Theory of the Intercultural," Res 35 (1999) 5-9, at 6 (emphasis ours). 
has been "resolved"). We would not, therefore, expect the recognition, much less the shock, of this exoticism to last for generations - at least, not without its ongoing cultivation by hegemonic power. Over time, elements lose their exoticism and may eventually become indigenized in their new settings. ${ }^{32}$

It is thus incumbent upon the scholar of late antique magic not only to examine the elements that occur on a given amulet from the perspective of origins, but also to consider the historical and social conditions behind a possible "exotic" element or cluster of elements. Would such conditions make it more likely that the elements were consciously deployed with their exotic connotations intact or, conversely, that they were absorbed into the dominant tradition?

That religious traditions absorb "exotic" elements should also make us attuned to the nature of religious boundaries during late antiquity, which were hotly contested and subject to continual renegotiation. ${ }^{33}$ In some cases, the movement of words, symbols, objects, and practices across boundaries were relatively rare, one-time events. In other cases, these "exotic" elements were subsequently naturalized within their new contexts or even supplied with fictive genealogies. ${ }^{34}$

The operative taxonomies we use to organize and analyze our sources ought to reflect these dynamic configurations of religious boundaries during late antiquity. As we argue at length below, magical texts that appear to contain Jewish elements should most often be seen as

\footnotetext{
${ }^{32}$ Walker hints at this point when she notes that "indigenous" and "foreign" cultures "were themselves the products of hybrid combinations that were in constant reformulation" (Walker, Emperor and the World, xx).

${ }^{33}$ See, e.g., Paula Fredriksen, "What Parting of the Ways? Jews and Gentiles in the Ancient Mediterranean City," in The Ways that Never Parted: Jews and Christians in Late Antiquity and the Early Middle Ages (ed. Adam Becker and Annette Yoshiko Reed; Minneapolis: Fortress Press, 2007; repr. Tübingen: Mohr Siebeck, 2003) 35-63; Judith Lieu, "Self-Definition vis-à-vis the Jewish Matrix," in The Cambridge History of Christianity (ed. Margaret M. Mitchell and Francis Young; Cambridge: Cambridge University Press, 2006) 214-29. The boundaries between Jews and Christians continued to be hotly contested throughout late antiquity on various social, symbolic, and political registers. On this point, see Joseph E. Sanzo and Ra'anan Boustan, "Mediterranean Jews in a Christianizing Empire," in The Cambridge Companion to the Age of Attila (ed. Michael Maas; Cambridge: Cambridge University Press, 2014) 358-75.

${ }^{34}$ Gideon Bohak uses a model taken from Immigration and Naturalization Services to describe such crossings in Jewish magic; see Bohak, Ancient Jewish Magic, 229-30.
} 
evidence that the categories formulated by modern scholars have more in common with the preferences of various ancient elites than with the actual language found on the magical objects themselves. We must, therefore, be careful of recapitulating the perspectives of the elite gatekeepers. Certainly, ecclesiastical authorities like John Chrysostom argued that many Christians put a great deal of stock in the powers of Jewish practitioners and were likely to be impressed by a ritual practice or text that was liberally flavored with the spice of "Jewish" words and symbols. ${ }^{35}$ But the rhetoric of figures like Chrysostom, who harnessed the discourse of "magic" in order to sharpen the distinction between "Christianity" and "Judaism," should not serve as the basis for conceptualizing our own scholarly taxonomies of late antique magical practice. We must instead turn to the artifacts themselves to consider the light they shed on the conceptions of religious proximity or distance with which Christian ritual practitioners actually operated.

\section{III. “Jewish” Elements in Christian Magic}

A number of amulets and magical books that were likely produced by and/or for Christians incorporate what appear to be Jewish elements. ${ }^{36}$ Most of these devices-like P.Oxy. VIII 1152, discussed at the outset of this paper-bear no linguistic or material signs that would indicate whether or not the practitioner capitalized on or even recognized such elements as

\footnotetext{
${ }^{35}$ For prudent discussion of the relevant sources, see ibid., 314-22.

${ }^{36}$ The identification of at least some practitioners as "Christian" is supported by the use of Christian idioms, such as Trinitarian invocations, biblical citations, and excerpts from the Christian liturgy, on numerous amulets and spells from late antiquity. For collections of such artifacts, see de Bruyn and Dijkstra, "Greek Amulets"; Theodore de Bruyn, "Papyri, Parchments, Ostraca, and Tablets Written with Biblical Texts in Greek and Used as Amulets: A Preliminary List," in Early Christian Manuscripts: Examples of Applied Method and Approach (ed. Thomas J. Kraus and Tobias Nicklas; Leiden: Brill, 2010) 145-90; idem, "The Use of the Sanctus in Christian Greek Papyrus Amulets," in Papers Presented at the Fourteenth International Conference on Patristic Studies Held in Oxford 2003: Liturgia et Cultus, Theologica et Philosophica, Critica et Philologica, Nachleben, First Two Centuries (ed. Mark J. Edwards, Francis Margaret Young, and Paul M. Parvis; Leuven: Peeters, 2006) 15-20. On the use of onomastics to determine the Christian affiliation of the client, see Walter Shandruk, "Christian Use of Magic in Late Antique Egypt," JECS 20 (2012) 31-57.
} 
Jewish. ${ }^{37}$ But some artifacts do provide us with valuable insight regarding the stance that a practitioner has adopts vis-à-vis the various elements that make up his amulet or spell. In this and the following sections, we demonstrate the range of tactics that were available to Christian ritual practitioners when making use of what modern scholars have labeled as Jewish elements. This survey will allow us to formulate some general working principles that we think should inform future scholarly consideration of this phenomenon.

The task of studying the use of Jewish elements in Christian magic poses special methodological challenges. In the first place, Christian practitioners inherited a trade from earlier (and perhaps contemporary) non-Christian practitioners in Egypt, mostly non-Jewish, for whom many of the so-called Jewish items were probably not recognized or utilized as such. This process of indigenization is compounded in the case of Christian magic. Christian ritual practitioners participated —at least to some extent—in the wider Christian culture of late antiquity that increasingly embraced the "Old Testament" as the prophetic forerunner of the "New" and viewed the Christian Church as the True Israel that had inherited the Abrahamic covenant. ${ }^{38}$ Because of this supersessionist logic, Christian practitioners would have been even less likely than their "Pagan" counterparts to have conceived of the so-called Jewish items they cited in their amulets and spells (e.g., Old Testament texts and idioms derived from them) as Jewish, but would have treated them as simply Christian. ${ }^{39}$ Indeed, many of these elements had

\footnotetext{
${ }^{37}$ See, e.g., PGM P15b; PGM P14; PGM P21; ACM 4; ACM 59; ACM 61; ACM 62; ACM 63; ACM 64; ACM 66; ACM 68; ACM 70; ACM 71.

${ }^{38}$ On supersessionist discourse in early Christian literature, see Terry Donaldson, "Supersessionism and Early Christian Self-Definition," in Ambiguities, Complexities, and Half-Forgotten Adversaries: Crossing Boundaries in Ancient Judaism and Early Christianity (ed. Andrea Lieber and Kimberly B. Stratton; Leiden: Brill, forthcoming); also Stephen G. Wilson, Related Strangers: Jews and Christians 70-170 C. E. (Minneapolis, MN: Fortress Press, 2004) 110-42.

${ }^{39}$ This idiomatic overlap makes it difficult in some cases to determine whether an amulet reflects a “Jewish" or "Christian” magical tradition; see Bohak, Ancient Jewish Magic, 212-14.
} 
long been integral to Christian symbolic systems, in some cases from the first phases of the early Jesus-movement.

Some Christian artifacts bear witness to the process of indigenization by which originally Jewish elements became Christianized—and thus in a very real sense no longer Jewish. This process is perhaps best exemplified by Brit. Lib. Or. 6796(4), 6796 (=ACM 132), a seventhcentury C.E. exorcistic spell written in Coptic across two sheets of papyrus. ${ }^{40}$ The spell's strong emphasis on Jesus' passion suggests that the practitioner who created it was Christian or, at least, designed it for a Christian client. The text begins with a prayer of Jesus on the cross and a description of the events surrounding his crucifixion, mostly taken from the Gospel of Matthew. ${ }^{41}$ The same scribe responsible for the text of the exorcism also included a drawing of the crucifixion scene toward the bottom of the second sheet. Moreover, the theme of Jesus' crucifixion appears in another section of the text, which reports a conversation between the crucified Jesus and a unicorn (папітап моүФт). As part of this conversation, Jesus proclaims: "I am I(sra)êl Êl, the force (АYNamic) of Iaô Sabaôth, the great power (бом) of Barbaraôth." "42 Given the centrality of the crucifixion to this spell, there is little reason to suppose that either the practitioner or his client would have considered the divine name "I(sra)êl Êl"—most likely meaning "God of Israel" - to be a Jewish magical tradition. As it is Jesus who bears the title, this particular divine name has literarily been Christianized. ${ }^{43}$

\footnotetext{
${ }^{40}$ A. Kropp, Ausgewählte koptische Zaubertexte (3 vols.; Brussels: Édition de la Fondation égyptologique Reine Élisabeth, 1930-1931) 1:47-50 (J); 2:57-62 (XV).

${ }^{41}$ For an analysis of the use of biblical traditions on this spell, see Joseph E. Sanzo, "Innovation and Authoritative Traditions for Ritual Power: The Crucifixion of Jesus on Brit. Lib. Or. 6796(4), 6796 as a Test Case," ARG 17 (forthcoming 2015).

${ }^{42}$ Translation adapted from ACM 132. For Barbaraôth (and cognates), see PGM III.633-731; PGM IV.8893; PGM IV.930-1114; PGM V.54-69.

${ }^{43}$ We thus disagree with the interpretation of Jarl Fossum in "Sects and Movements," in The Samaritans (ed. Alan David Crown; Tübingen: Mohr Siebeck, 1989) 293-389, which argues that Israêl Êl is a distinct angel in this spell (370). But, crucially, this same ritual specialist uses a similar formula in another spell (ACM 131): "I invoke you today, send to me from heaven the prayer of Koutha Iaô, god of the Hebrews, who is described in the
} 
In addition, all indications suggest that this practitioner did not consider Iaô Sabaôth to be Jewish — or Pagan, for that matter — but rather to be one of the Christian names of the Father, with the crucified Jesus as the force (AYNamic) of Iaô Sabaôth. ${ }^{44}$ That Jesus and the Father fall within the same theological framework for this practitioner is further reinforced in subsequent sections of the spell, in which the practitioner highlights the Father's approval of Jesus by including the names that he spoke over the crucified Jesus' head (11. 23-26) and by calling upon the Father to send his son (11. 31-45). Likely with such paternal connotations in mind, the practitioner incorporates Iaô Sabaôth into the drawing of the crucifixion on the second sheet. ${ }^{45}$ In short, all signs suggest that this practitioner did not consider these names to be marked Jewish elements, but rather to be part-and-parcel of a genuinely Christian ritual discourse. ${ }^{46}$ Brit. Lib. Or. 6796(4), 6796 likely characterizes how most Christian practitioners from late antiquity deployed ostensibly Jewish elements. Indeed, much of the extant evidence suggests that magical names, formulae, or narrative traditions that may appear to modern scholars as heavens as Alamouri Malamouri." In what is either the same spell as or an appended spell to this latter one (Brit. Lib. Or. 6796 [1r], 1. 4), the practitioner refers to Jesus again as "the god of Israel" (п№үте $\bar{M} \Pi \overline{\mathrm{H} \lambda} \overline{\mathrm{IC}}$ ).

${ }^{44}$ The names Iaô and Sabaôth appear independent of one another in the Nag Hammadi codices. For Iaô, see NH II, 1.11.30; 12.20; II, 5.101.15, 29. For Sabaôth, see NH II, 1.10.34; 11.31; II, 4.95.14, 23; II, 5.101.30; 103.32; 104.6, 19, 26; 106.20, 25; 107.5; 113.12; 114.16; 122.23; III, 2.58.15; IV, 1.26.19; IX, 3.73.30. For a recent analysis of Iaô (and derivative expressions) in Greek and Coptic magical texts, see Wolfgang Fauth, Jao-Jahwe und seine Engel: Jahwe-Appellationen und zugehörige Engelnamen in griechischen und koptischen Zaubertexten (Tübingen: Mohr Siebeck, 2014).

${ }^{45}$ Compare the London Hay "Cookbook" (=ACM 127), a $6^{\text {th }}$ - or $7^{\text {th }}$-cent. C.E. collection of spells also presumably written and/or collected by a self-identifying "Christian," which likewise names Jesus' Father Iaô Sabaôth-using a variant spelling of this name. The text reads, "[I adjure] you by the great, true name of the father, whose name is Aio Sabaôth..."

${ }^{46}$ A similar situation presents itself for Prague 1 (=ACM 36), an artifact for success, which reads: "I invoke you, $\mathrm{O}$ god almighty, who is above every ruler and authority and lordship and every name that is named, who is enthroned above the cherubim before you, through our lord Jesus Christ, the beloved child. Send [out] to me, O master, your holy] archangels, who stand opposite your holy altar and are appointed for your holy services, Gabriêl, Michaêl, Raphaêl, Saruêl, Raguêl, Nuriêl, Anaêl. And let them accompany me today, during all the hours of day and night, and grant me victories, favor, good luck with N., success with all people, small and great, whom I may encounter today, during all the hours of day and night. For I have before me Jesus Christ, who attends me and accompanies me; behind me Iaô Sabaôth Adô[nai]; on my right and [left] the god of Ab[raham, Isaac, and Jacob]; over [my] face [and] my heart Ga[briêl, Michaêl], Raphaêl, Saruêl, [Raguêl], Nuriêl, Anaêl: [Protect] me from every [demon, male or female, and from] every stratagem and from every name, for I am sheltered under the wings of the cherubim. O Jesus Christ, you king of all the aeons, almighty, inexpressibly a creator, nurturer, master, almighty, noble child, kindly son, my unutterable and inexpressible name, truly true form, unseen [for] ever and ever, Amen! By the saints remember me, pray for me; I am without strength." 
quintessentially Jewish were readily indigenized within Christian magical culture. Nevertheless, it is necessary to expand and complicate this picture of appropriation. In the following sections, we analyze a series of cases in which "Jewishness" figures prominently in Christian magical texts. We first consider examples in which so-called Jewish elements are utilized as a positive or constructive resource for ritual efficacy. We then discuss cases in which Christian practitioners juxtapose what scholars generally regard as "Jewish" elements with overly anti-Jewish rhetoric. Given the harsh anti-Jewish invective used in these texts, we find it unlikely that these practitioners capitalized on some kind of Jewish exoticism, but instead regarded such elements as Christian. Taken together, the artifacts discussed in the following sections thwart simplistic accounts of the relationship between the Jewish and Christian magical traditions.

\section{Jewish Ritual Authority in Christian Magic}

We have thus far cautioned that scholars must consider the dynamics of reception and indigenization when seeking to determine whether it is appropriate to label a given element as Jewish within Christian contexts of use. At the same time, some ritual artifacts that appear to have been produced or used by Christians do employ idioms or formulae that are drawn from contemporaneous Jewish magical discourse. We argue here that, in such cases, the "Jewish" character of these particular elements was not only perceptible to the practitioners and the clients, but was also important to the ritual efficacy of the artifacts in which those elements appear.

One of the most plausible cases of this phenomenon is a group of five incantation bowls from Sasanian Iraq written in Syriac script that employ a version of the Jewish get (divorce) formula alongside a reference to Rab (or Rabbi) Joshua bar Perahya for apotropaic or healing 
purposes. ${ }^{47}$ Numerous Jewish incantation bowls from late antiquity also link the divorce formula to Joshua bar Perahya, ${ }^{48}$ who, according to rabbinic literature, lived during the Hasmonean period in the late second and early first centuries B.C.E. and, among other things, was among the "pairs" (zugot) who transmitted the Torah to the rabbis. ${ }^{49}$ This conjunction of Syriac script with Jewish magical traditions requires us to consider the possibility that the exoticism of marked Jewish elements contributed to the protection and healing such artifacts were thought to mediate. Typical of this cluster of Syriac-script incantation bowls that invoke the ritual-legal authority of Joshua bar Perahya is CBS 16086, which was excavated in the late nineteenthcentury at Nippur and is now housed at the University of Pennsylvania Museum. The opening of the text inscribed on this bowl reads as follows:

1. Prepared is this bowl for the sealing of the house

2. and of the wife and of the sons of dynwy son of 'yspndrmyd, that may depart from him the mevakkalta

3. and the evil dreams. The lot I cast and I take, magical act that was performed

4. like it was when Rabbi Joshua bar Perahya sat (in court), and wrote against them a bill of divorce against all of them: demons and devils

5. and satans and liliths and no-good-ones that are in the house of dynwy son of 'yspndrmyd. Again, he wrote against them a bill of divorce that is forever. ${ }^{50}$

${ }^{47}$ See now Marco Moriggi, “Jewish Divorce Formulae in Syriac Incantation Bowls,” Aramaic Studies 13 (2015) 82-94; also Shaul Shaked, "The Poetics of Spells: Language and Structure in Aramaic Incantations of Late Antiquity, 1: The Divorce Formula and its Ramifications," in Mesopotamian Magic: Textual, Historical, and Interpretative Perspectives (ed. Tzvi Abusch and Karel van der Toorn; Groningen: Styx, 1999) 173-95, especially his discussion of the Syriac exemplars at 176 n. 17 and 184 n. 41. It should be noted that there are also examples of Mandaic bowls that likewise employ the divorce formula. See Erica C. D. Hunter, "Combat and Conflict in Incantation Bowls: Studies on Two Aramaic Specimens from Nippur," in Studia Aramaica: New Sources and New Approaches (ed. M. J. Geller, J. C. Greenfield, and M. P. Weitzman; Oxford: Oxford University Press on behalf of the University of Manchester, 1995) 61-75.

${ }^{48}$ In addition to the foundational discussion in Shaked, "The Poetics of Spells," see also Gideon Bohak and Dan Levene, "Divorcing Liliths: From the Babylonian Incantation Bowls to the Cairo Genizah," JJS 63 (2012) 198217, at 209; and Dan Levene, “'A Happy Thought of the Magicians': The Magical Get," in Shlomo: Studies in Epigraphy, Iconography, History and Archaeology in Honor of Shlomo Moussaief (ed. Robert Deutsch; Tel Aviv: Archaeological Center Publications, 2003) 175-84.

${ }^{49}$ See $m A v o t$ 1:6. For discussion of the structure and names in the list in chapter 1 of the tractate, see Amram Tropper, Wisdom, Politics, and Historiography: Tractate Avot in the Context of the Graeco-Roman Near East (Oxford: Oxford University Press, 2004) 40-41.

${ }^{50}$ The translation is taken from Marco Moriggi, A Corpus of Syriac Incantation Bowls: Syriac Magical Texts from Late-Antique Mesopotamia (Leiden: Brill, 2013) 37 (bowl no. 4); ed. princ. James A. Montgomery, Aramaic Incantation Texts from Nippur (Philadelphia: The University Museum, 1913) no. 32. For parallel bowls, see Moriggi, Corpus of Syriac Incantation Bowls, 43-45 (no. 5), 150-53 (no. 31), 163-64 (no. 34), and 185-88 (no. 
The ritual specialist who created this text explicitly authorizes the use of a "bill of divorce" against the demons by appealing to the judicial activity of "Rabbi"51 Joshua bar Perahya, who appears to have established the precedent for this application of such documents. ${ }^{52}$ It may perhaps be significant that the technical term that the Syriac texts use to refer to the divorce

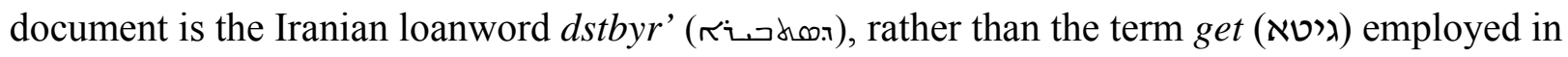
the Jewish Aramaic parallels. ${ }^{53}$ Yet, as a number of scholars have shown, despite this terminological difference and some other minor discrepancies, the text of the bowl in the looping Syriac script powerfully resembles — and was almost certainly taken over from - the examples of this tradition written in the square Jewish Aramaic. ${ }^{54}$

The particular intersection of script and content on these bowls requires us to entertain at least two scenarios. A first scenario entails a Christian practitioner and a Christian client. This scenario is the most likely option given the abundance of texts and artifacts linking the Syriac script with Christian communities. ${ }^{55}$ Of course, such a practitioner-client arrangement raises the

41). Compare also the Mandaic bowl Louvre A.O. 2629, ed. princ. M. Lidzbarski, Ephemeris für semitische Epigraphik I (Giessen, 1902) 103-5 (Text V), discussed in Hunter, "Combat and Conflict," 61-75.

${ }^{51}$ The nomenclature used here is "Rabbi" (

52 (Rabbi) Joshua bar Perahya is the human authority who is most closely linked to the establishment and efficacy of this practice in both the Jewish and the non-Jewish bowls. He is explicitly mentioned in sub-groups A and C in Shaked's typology; see Shaked, "Poetics of Spells," 176-77 and 183-84.

${ }_{53}$ On the use of this term in the Syriac bowls, see the comments in Moriggi, Corpus of Syriac Incantation Bowls, 39; also the relevant entry in Claudia A. Ciancaglini, Iranian Loanwords in Syriac (Wiesbaden: Ludwig Reichert Verlag, 2008) 153.

${ }^{54}$ See Moriggi, "Jewish Divorce Formulae," 85-91, which conclude that it seems to be only Shaked's type A that was adopted in the Syriac bowls. For the synoptic comparison of CBS 16086 (=Moriggi's bowl 4) with three Jewish Aramaic parallels, see especially Dan Levene, A Corpus of Magic Bowls: Incantation Texts in Jewish Aramaic from Late Antiquity (repr. ed.; London: Routledge, 2009) 35-37, who likewise concluded that "the source is indeed Jewish" (38).

${ }^{55}$ On the close link between the Syriac script and Christian communities, see Shaul Shaked, "Manichaean Incantation Bowls in Syriac," Jerusalem Studies in Arabic and Islam 24 (2000) 58-92, at 59-60. It should be stressed that, the designation of the script as "Manichaean" is on purely paleographic grounds and that this term should not be taken as an indicator of the scribes' religious affiliation. For in-depth discussion of the history and significance of the application of the label "Manichaean" to the script used in a subset of the Syriac bowls, see Moriggi, Corpus of Syriac Incantation Bowls, 14-19. 
question of why a Christian practitioner, presumably writing for a Christian client, would cite a "Jewish" divorce formula and reference Joshua bar Perahya.

Exacerbating the problem of interpreting what this bowl might tell us about the Christian use of Jewish magical idioms is the current scholarly conundrum regarding the social and scribal milieus through which the divorce formula entered into and disseminated in Syriac Christian contexts. According to Shaul Shaked, the Syriac bowls represent "a transcription from a Jewish Aramaic model (or from an oral formula first uttered in Jewish Aramaic). ${ }^{, 56}$ This quite reasonable hypothesis, however, does not yet allow us to determine with any degree of certainty whether the Syriac Christian practitioners behind the extant exemplars would have associated this formula with Jewish ritual experts or with the larger Jewish world. They might equally have viewed the use of the divorce formula as belonging to the general milieu in which they were operating, which was in any case characterized by porous boundaries and an eclectic religious sensibility. ${ }^{57}$

Yet there is the stubborn association of this practice with a named figure whose literary and cultural context is so clearly linked to contemporaneous Jewish traditions and communities. It is interesting to consider that, according to the Babylonian Talmud, Joshua bar Perahya had been the teacher of Jesus the Nazarene in Egypt before he rejected his disciple for "practicing magic and leading Israel astray.. ${ }^{, 58}$ Apparently, then, in the rabbinic culture of Sasanian Iraq Joshua bar Perahya was not only linked to magical knowledge and power, but also was

${ }^{56}$ Shaked, "Poetics of Spells," 176 n. 17.

${ }^{57}$ See especially Michael G. Morony, "Magic and Society in Late Sasanian Iraq," in Prayer, Magic, and the Stars in the Ancient and Late Antique World (ed. Scott Noegel, Joel Walker, and Brannon M. Wheeler; University Park, Pa.: Pennsylvania State University Press, 2003) 83-107, at 94-95, who builds upon the synthetic assessment in Tapani Harviainen, "Pagan Incantations in Aramaic Magic Bowls," in Studia Aramaica: New Sources and New Approaches (ed. M. J. Geller, J. C. Greenfield, and M. P. Weitzman; Oxford: Oxford University Press on behalf of the University of Manchester, 1995) 53-60; idem, "Syncretistic and Confessional Features in the Mesopotamian Incantation Bowls," Studia Orientalia 70 (1993) 29-37.

${ }^{58}$ See bSanh $107 \mathrm{~b}$; cf. bSota $47 \mathrm{~b}$. 
associated with Jesus himself. ${ }^{59}$ It is difficult to know whether the master-disciple relationship of Joshua bar Perahya and Jesus, as depicted in the Babylonian Talmud, was known to the Christian scribes who incorporated the name of this Jewish authority into their ritual praxis. And, even if it was known to them, they surely did not share its negative portrait of Jesus. Nevertheless, we must consider the possibility that the figure of Joshua bar Perahya and the ritual strategy associated with him was made especially attractive to these Christian ritual experts because of his general association with magical power as well as the all-important figure of Jesus.

A second scenario worth entertaining is that these particular Syriac bowls containing Jewish elements were produced by non-Christian ritual experts, presumably Jews. According to this scenario, these practitioners would probably have created the bowls for Christian clients who would have found the Syriac script desirable. While limited, there is clear evidence that nonChristians utilized the Syriac script. In the fourth to sixth centuries C.E., Syriac in the Estrangelo script was not confined to Christian contexts, but represented a regional "lingua franca in large areas of the western provinces of the Sasanian empire and beyond" and was thus also used by non-Christians as well. ${ }^{60}$ Moreover, as is evident from a number of medieval Jewish texts that have taken over Christian materials in Syriac, some Jewish scholars appear to have had access to texts in Syriac language and script ${ }^{61}$ It should be stressed that even this scenario points to the important fact that a Jewish tradition found an audience in a script that was primarily associated with Christian contexts.

\footnotetext{
${ }^{59}$ For discussion of the Bavli traditions about Joshua bar Perahya and Jesus in the wider context of the Jewish and Christian magical bowls, see Peter Schäfer, Jesus in the Talmud (Princeton, N.J.: Princeton University Press, 2008) 34-40.

${ }^{60}$ Shaked, "Manichaean Incantation Bowls in Syriac," 60.

${ }^{61}$ The clearest and most well known example is the relatively late Targum Proverbs, which is an almost word-for-word version of the Syriac Peshitta. For brief discussion and relevant scholarship, see Paul V. M. Flesher and Bruce Chilton, The Targums: A Critical Introduction (Leiden: Brill, 2011) 259-60.
} 
For the purposes of this essay, we follow current scholarly wisdom in Syriac studies and, consequently, presume that Christian practitioners composed this group of bowls. Nevertheless, we think that the Syriac incantation bowls deserve further study as it pertains to the relationship between scripts and religious communities. Indeed, if it could be shown that the ritual experts who produced these particular bowls were Jews who otherwise wrote in Jewish Aramaic script, that finding would be of enormous interest in its own right, suggesting an even higher degree of contact and fluidity across religious boundaries than most scholars now imagine.

In sum, we would suggest that what we find in this group of Syriac bowls is a "Jewish" divorce formula and a figure overtly labeled with the technical term "Rab" or "Rabbi" having found their way into a Christian text, presumably without having lost their "Jewish" associations. This scenario strongly implies that there were Christian practitioners who drew on the power believed to inhere in Jewish exoticism. It would seem that CBS 16086 and similar bowls exemplify the degree to which Jewish ritual experts and their non-Jewish counterparts could participate in a shared magical culture. At the same time, these bowls embody the difficulties that often confront the scholar when attempting to identify indigenous and exotic elements on specific Christian artifacts.

\section{Jewish Difference as Ritual Resource in Christian Magic}

In the examples discussed above, Christian ritual experts were either unaware of the presence of possible Jewish elements in their spells or, by contrast, intentionally capitalized on Jewish exoticism for generating ritual efficacy. But the extant evidence reveals other ways that Christian practitioners negotiated "Jewish" similarity and difference. At least certain practitioners - presumably Christian — appropriated negative discourses of Jewish otherness for 
efficacy. This fact is hardly surprising since the "Jews" as an oppositional category figured so prominently in the construction of Christian identity throughout late antiquity. In particular, the Jews were not only blamed for the death of Christ—a point hinted at in the three examples to follow - but they were also used as an orienting metaphor for numerous forms of heresy against which Christian orthodoxy sharpened itself. ${ }^{62}$ It is no surprise, therefore, that in recent decades scholars have stressed the central function of Jews and Judaism in the formation of Christian identity. ${ }^{63}$

But it must be stressed that even those Christian magical artifacts that demonstrate a sensitivity to religious distinction do not necessarily operate according to the taxonomies to which modern scholarship is accustomed. More often than not, the categories of religious identity operative in these texts stand in tension or even conflict with those deriving from origins or idealized ecclesiastical tradition.

For instance, P.Heid. inv. G 1101 (=Suppl.Mag. 32), a fifth- or sixth-century C.E. Greek amulet from Egyptian Babylon that was designed to heal eye discharge ( $\dot{\rho} \varepsilon \tilde{u} \mu \alpha)$, utilizes elements that scholars typically label "Jewish," while also emphasizing Jewish difference. ${ }^{64}$ Thus, in a lacunose section at the beginning of its text, the practitioner adjures Toumêel Êl (1. 3) —an ad hoc name that seems to be playing on the Hebrew -êl endings. ${ }^{65}$ The practitioner then presumably adjures the six-winged seraphim from the Septuagint translation of Isaiah 6, writing,

\footnotetext{
${ }^{62}$ See Averil Cameron, "Jews and Heretics-A Category?" in The Ways that Never Parted: Jews and Christians in Late Antique and the Early Middle Ages (ed. Adam Becker and Annette Yoshiko Reed; Minneapolis: Fortress Press, 2007; repr. Tübingen: Mohr Siebeck, 2003) 345-60; David Brakke, "Jewish Flesh and Christian Spirit in Athanasius of Alexandria," JECS 9 (2001) 453-81. That at least some late antique ritual experts were familiar with contemporary constructs of orthodoxy is suggested by the several amulets that utilize creeds and other symbolic markers of Christian orthodoxy (e.g., Suppl.Mag. 23, Suppl.Mag. 31, and PGM P16).

${ }^{63}$ See, most recently, Andrew S. Jacobs, Christ Circumcised: A Study in Early Christian History and Difference (Philadelphia, Pa.: University of Pennsylvania Press, 2012). $149-170$.

${ }^{64}$ Ed. princ. Franco Maltomini, “Cristo all'Eufrate P. Heid.G.1101: Amuleto cristiano,” ZPE 48 (1982)

${ }^{65}$ Lacerenza, "Jewish Magicians and Christian Clients," 407, claims that such -êl endings "were created in order to lend a more reliable Semitic or Jewish habitus to the text."
} 
"I adjure those who say, 'Holy, Holy, Holy' Lord of Sabaôth" (1. 6). This reference is further qualified with the phrase, "the God Adonaei Aoth" (1. 6) Finally, at the end of the ritual text, the practitioner calls upon the angels Michaêl, Gabriêl, Ourêêl, and Raphaêl to undo quickly the pains caused by the eye discharge (11. 11-12).

Yet, despite this apparent pattern of Jewish or Hebrew names, orthographical peculiarities, and references, this amulet includes the following historiola (or short narrative used for ritual power):

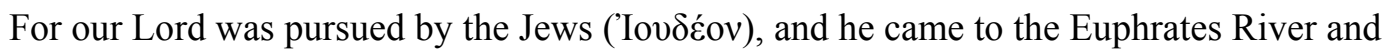
stuck in his staff, and the water stood still. Also you, discharge $(\dot{\rho} \varepsilon \tilde{v} \mu \alpha)$, stand still from head to toe-nails in the name of our Lord, who was crucified (11. 8-11). ${ }^{66}$

In this historiola, the practitioner establishes the setting of Jesus' otherwise unattested miracle at the Euphrates River with a reference to the Jewish pursuit of Jesus - perhaps partly inspired by the Exodus story. ${ }^{67}$ Since Jesus is the protagonist of this ritual text, it is clear that the Jews here were understood as antagonists. Given the overall anti-Jewish rhetoric of the text, it makes little sense to say that its creator understood elements such as Adonaei and the angels to be Jewish in any meaningful sense. Instead, the practitioner seems to have operated according to a taxonomy in which these so-called Jewish elements were considered part of the same tradition as Jesus. The co-presence of these elements should not be viewed by scholars as the juxtaposition of Jewish and Christian elements, but instead as an internally coherent idiom that reflected and gave expression to the practitioner's version of Christianity. ${ }^{68}$

${ }^{66}$ Translation adapted from Suppl.Mag. 32.

${ }^{67}$ For the possible sources behind this historiola, see Maltomini, "Cristo all'Eufrate P. Heid.G.1101," 15256; Gianfranco Fiaccadori, “Cristo all'Eufrate (P. Heid. G. 1101, 8 ss.)," La parola del passato 41 (1986) 59-63; Roberta Mazza, "P.Oxy. XI, 1384: Medicina, rituali di guarigione e Cristianesimi nell'Egitto tardoantico," ASE 24 (2007) 437-62, at 444-45.

${ }^{68}$ Joseph E. Sanzo, “'For our Lord was pursued by the Jews...': The (Ab)Use of the Motif of 'Jewish' Violence against Jesus on a Greek Amulet (P. Heid. 1101)," in One in Christ Jesus: Essays on Early Christianity and "All that Jazz," in Honor of S. Scott Bartchy (ed. David Matson and K. C. Richardson; Eugene, OR: Pickwick Publications, 2014) 86-98, at 95-96. 
We are confronted with a similar situation in P.Oxy. LXV 4469, a late-fifth-century C.E. healing amulet from Oxyrhynchus, Egypt. The greater part of the amulet consists of a citation in Greek of the pseudepigraphical letter of Abgar, king of Edessa, to Jesus, with the client's name, written in Coptic, inserted into this passage. At the end of the ritual text, the practitioner references the following names (in Greek): Iaô Sabaôth, Elôe, and Adônai. Despite using names that some scholars might label as Jewish, the practitioner includes in his citation of Abgar's letter the reference to the Jewish persecution of Jesus. In the Eusebian version of Abgar's letter, the reference to the Jewish persecution of Jesus reads as follows: "I heard that the Jews are mocking you, and wish to ill-treat you." ${ }^{69}$ But P.Oxy. LXV 4469 offers an even more negative - and otherwise unattested - version of this statement: "for I have heard that the Jews murmur against you and persecute you, desiring to kill you." ${ }^{, 70}$ Again, like P.Heid. inv. G 1101, the practitioner highlights religious difference between Christians and Jews, but does so based on a taxonomy in which Iaô Sabaôth, Elôe, and Adônai are classed under the taxon "Christian." Like these two Greek exemplars, P.Anastasy 9 (=ACM 134), a sixth-century C.E. Coptic codex that was used for apotropaic and other magical purposes, juxtaposes ostensibly Jewish elements and anti-Jewish invective. ${ }^{71}$ Some of the texts in this codex correspond to those known from other contexts (e.g., The Letter of Abgar to Jesus, The Letter of Jesus to Abgar, and the Gospel incipits), while two seem to be original compositions of the scribe (a prayer and

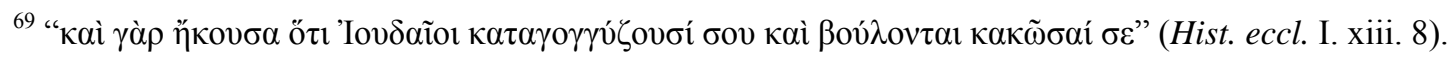
Translation taken from Eusebius, The Ecclesiastical History, Books I-V (trans. Kirsopp Lake; LCL 153; Cambridge: Harvard University Press, 2001) 89.

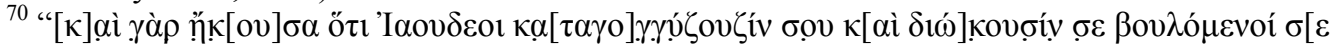
$\dot{\alpha} \pi \mathrm{o}] \kappa \tau[\varepsilon \tilde{\mathrm{i}} \boldsymbol{\alpha} \alpha \mathrm{l}]$." While this version is otherwise unattested, it does have affinities with the Syriac tradition of the same letter; see Franco Maltomini, “4469. Letter of Abgar to Jesus [Amulet],” in The Oxyrhynchus Papyri (ed. M. W. Haslam, A. Jones, et. al.; vol. 65; London: Egypt Exploration Society, 1998) 122-29, at 124.

${ }^{71}$ Ed. princ. Willem Pleyte and Pieter Adrian Art Boeser, Manuscrits coptes du Musée d'antiquités des Pays-Bas à Leide (Leiden: Brill, 1897) 441-79.
} 
exorcism attributed to Gregory [Nazianzus?] and an untitled text). ${ }^{72}$ In the material attributed to Gregory, the practitioner calls upon the archangels Michaêl, Gabriêl, Raphaêl, Ouriêl, Sedekiêl, Anaêl, Setêl, Azaêl (4r, 11. 14-23). ${ }^{73}$ He also includes in this text an extended invocation that draws on the precedent established by God's interventions on behalf of the people of Israel:

I adjure all you violent deeds, by the great glorious name (of) god almighty, who brought his people out of the land of Egypt with a strong hand and a raised arm, who struck Pharaoh and his entire force, who spoke with Moses on Mount Sinai, who gave his law and his commandments to the children of Israel and made $<$ them $>$ eat manna, that you flee far away and not at all continue to stay in the place where this prayer is deposited. $(3 \mathrm{v}, 11.5-26)$

Alongside this litany of redemptive events, the text invokes the father using what might be interpreted as a Jewish or Hebrew formula, "Adônai Elôei Elemas Sabaôth." Significantly, this divine epithet appears in two different sections of the codex, in the text attributed to Gregory (1r, 11. 9-10; 2v, 5-6) and in the untitled text (9r, 11. 14-15). In addition, various other formulae that might be labeled Jewish or Hebrew appear in the codex. ${ }^{74}$ We might be tempted to view these elements, especially when taken together, as strategic appropriations of Jewish elements.

Nevertheless, the scribe responsible for this codex highlights the charge of Jewish culpability for the persecution and death of Jesus. The untitled composition in the codex instructs: "Rejoice, all you creatures, for the lord has risen from the dead on the third day and freed the whole race of Adam. He has destroyed the Jews who were ashamed on account of what

${ }^{72}$ In his translation of this artifact in ACM 134, Richard Smith misinterpreted the title at the end of the Prayer and Exorcism of Gregory as the title for the following text, thus identifying the untitled text as "The Prayer of Saint Gregory." We are grateful to Jacques van der Vliet for drawing this error to our attention.

${ }_{73}$ In 3r, 11. 16-17, only Michaêl, Gabriêl, Raphaêl, and Uriêl are mentioned. In the untitled text $(9 \mathrm{v}, 11.14$ 15), the archangels Michaêl, Gabriêl, Raphaêl, Uriêl, Sedekiêl, Anaêl, Setêl, Azaêl are invoked. On the use of

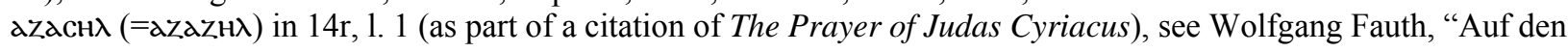
Spuren des biblischen 'Azazel (Lev 16): Einige Residuen der Gestalt oder des Names in jüdisch-aramäischen, griechischen, koptischen, äthiopischen, syrischen und mandäischen Texten,” ZAW 110 (1998) 514-34, at 517.

${ }^{74}$ E.g., Jesus' heavenly Father is referred to as "the God of Abraham and Isaac and Jacob" (4r, 11. 5-8). For discussion of this divine epithet, see Martin Rist, "The God of Abraham, Isaac, and Jacob: A Liturgical and Magical Formula," JBL 57 (1938) 289-303. In addition, the citation of the Prayer of Judas Cyriacus praises God as follows: "For you are the king of Israel and the salvation of the world and Jerusalem, for ever and ever. Amen" (15r, 11. 1721). 
they did. ${ }^{.75}$ Moreover, the scribe also includes a version of the Letter of Abgar, although the anti-Jewish invective here is even more pronounced than in P.Oxy. LXV 4469:

I have heard that your race rejected your lordship. They live wickedly and enviously, and they prosecute you, not wanting you to reign over them. They are ignorant of this, that you are the king of those in the heavens and those who are upon the earth, (you) who gives life to everyone. What, however, is the people of Israel? A dead dog, since they reject the living god. For surely they are unworthy of your holy gift. $(12 \mathrm{r}, 11.16-12 \mathrm{v}, 6)$

In this version of Abgar's letter to Jesus, the practitioner makes several accusations against the Jews, including their rejection of Jesus and their desire to kill him. These themes also appear either implicitly or explicitly in P. Oxy. LXV 4469. But what is distinctive here is the comparison between Jews and dogs, which draws on the Christian claim that the Jews fell into kinship with dogs because of their rejection of Jesus. ${ }^{76}$ This Coptic codex, therefore, is unlikely to be citing elements that its creator or intended clients would have viewed as Jewish. Nor does it seem that such elements would have been used for their foreignness or exoticism. Instead, given his antagonistic attitude toward Jews and Judaism, the practitioner most likely understood these elements as Christian and cited them accordingly. While this codex most certainly draws a firm boundary between Christians and Jews, its implicit taxonomy of religious difference only partially overlaps with — and thus calls into question — modern scholarly labels of what constitutes a Jewish or Christian element.

The appropriation of such anti-Jewish invective in these artifacts may reflect the perceived importance of the client's proper standing with God for achieving ritual efficacy. The client's piety, often understood as a well-ordered religious identity, is sometimes made a precondition for the success of the spell. For example, P.Oxy. VI 924 (=ACM 15) exemplifies

${ }^{75}$ This theme is also highlighted in ACM 51, an $11^{\text {th }}$-cent. C.E. amulet designed to heal and protect a certain Poulpehepus from fever. In lines 15-21, the text reads: “...through the name and the nails that were driven into (?) the body of Manuel, our Nuel, our god on the cross, by the Jews..." For the ed. princ., see Anthony Alcock, "A Coptic Magical Text," BASP 19 (1982) 97-103.

${ }^{76}$ See, e.g., John Chrysostom, Adv. Jud. 1.2.1-2. On the comparison of Jews with dogs in the Middle Ages, see Kenneth Stow, Jewish Dogs: An Image and Its Interpreters (Stanford, Calif.: Stanford University Press, 2006). 
the importance of a pure Christian identity for ritual efficacy. The practitioner behind this fourthcentury C.E. amulet not only invokes the Trinity - interestingly, alongside Abrasax — but also includes the following words:

Truly guard and protect Aria from the one-day chill and from the daily chill and from the nightly chill and from the mild fever of [the top of the head]. You shall do these things [graciously] and

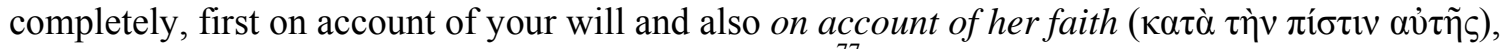
because she is a handmaid of the living god (11. 1-11). ${ }^{77}$

The ritual efficacy of this text depends, at least in part, on the client's "faith" ( $\pi i$ $\sigma \tau \imath)$, which serves as a basis for the appeal to the divine ("because she is a handmaid of the living god" [ö $\tau$ 1

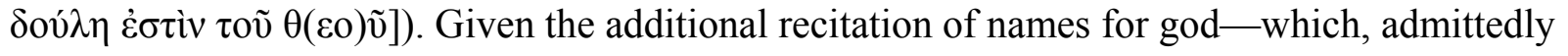

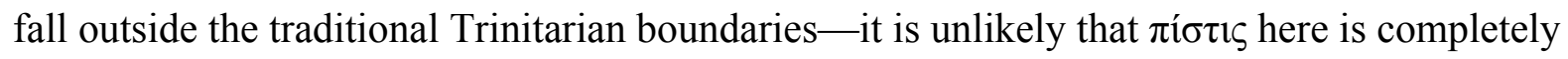
restricted to what we might call "devotion" (i.e., "faithfulness"), but comprised purity in all dimensions of the client's Christian faith, including the absence of heresy and improper social relations. $^{78}$

The practitioner's assumption aligns with a larger emphasis in ancient magic on proper standing with the divine, especially in cases in which the speaker makes demands on the entity invoked. In the words of David Frankfurter, "[i]n the case of the directive utterance, which includes prayer and magical command, the speaker's mind-set, preparation, traditional status, and purity are of paramount importance since the force of that utterance explicitly comes from

\footnotetext{
${ }^{77}$ Ed. princ. Bernard P. Grenfell and Arthur S. Hunt, "924. Gnostic Charm," in The Oxyrhynchus Papyri (ed. Bernard P. Grenfell and Arthur S. Hunt; vol. 6; London: Egypt Exploration Society, 1908) 289-90.

${ }^{78}$ For this more inclusive meaning of $\pi i \sigma \tau ı \zeta$ on amulets and prayers from late antique Egypt, see Anastasia Maravela, "Christians Praying in a Graeco-Egyptian Context: Intimations of Christian Identity in Greek Papyrus Prayers," in Early Christian Prayer and Identity Formation (ed. Reidar Hvalvik and Karl Olav Sandness; Tübingen: Mohr Siebeck, 2014) 291-323, at 299.
} 
that 'I' who says the words." ${ }^{, 79}$ It is important to note, therefore, that all of the aforementioned objects that deploy anti-Jewish invective also include commands as part of their ritual texts.

Given the importance of the Jewish foil for the creation and maintenance of Christian identity within late antiquity more generally, we propose that the aforementioned practitioners utilized anti-Jewish invective in order to distinguish their clients from the "Jews"-whether actual Jews or rhetorical Jews. In particular, practitioners appropriated motifs of boundary demarcation in order to demonstrate to God their clients' proper Christian identities vis-à-vis Jewish Others. ${ }^{80}$ The performance first establishes the purity of the client's Christian piety and then deploys that identity to ensure the efficacy of the ritual.

\section{Conclusions}

The artifacts studied above make it clear that no one model can account for the frequent use of ostensibly Jewish elements on Christian amulets and spells. Practitioners-like the authors of other discursive genres from late antiquity—constructed and appreciated religious difference in manifold ways. Thus, one cannot speak of a single approach to the boundaries between Judaism and Christianity in magical discourse any more than one can speak of a single perspective on the boundaries between Christianity and Judaism in late antique literary texts.

For this reason, we have attempted to let individual practitioners and artifacts speak for themselves. As we have seen, many, if not most, Christian amulets and spells (including P.Oxy. VIII 1152 cited in the introduction of this essay) do not contain sufficient information to enable scholars to determine how their Christian practitioners or clients categorized elements that

\footnotetext{
${ }^{79}$ David Frankfurter, "Narrating Power: The Theory and Practice of the Magical Historiola in Ritual Spells," in Ancient Magic and Ritual Power (ed. Marvin Meyer and Paul Mirecki; Leiden: Brill, 2001) 457-76, at 467.

${ }^{80}$ On this point, see Sanzo, "For our Lord," 94.
} 
appear to have their origins in Jewish contexts. It is, therefore, doubly difficult to say with any confidence that these Christian texts used Jewish idioms as foreign or exotic elements intended to enhance their ritual power.

In the face of this epistemological uncertainty, we have argued that these elements should not be made to conform to some idealized notion of the boundaries separating Judaism and Christianity. Such an operation runs the risk of distorting or even misrepresenting how their creators categorized these elements. A purely diachronic "etymological" approach to magical language tends to short-circuit consideration of how elements with diverse genealogies actually operated synchronically within a specific text or corpus. Rather, when seeking to determine which elements are foreign to or exotic within a religious tradition like Christianity, scholars ought to give due consideration to the native taxonomies that are operative within the artifacts themselves. Moreover, we have argued that, even in those cases where a practitioner seems to be pushing the limits of acceptable usage, the boundaries between traditions were rarely, if ever, governed by abstract rules.

Thus, we have seen that, in the case of the Syriac bowls that appealed to the ritual and legal authority of Joshua bar Perahya and his practice of using a divorce document to ward off the demons, the presumably Christian scribes who produced these texts were likely cognizant of the Jewish origins of this tradition; indeed, they may even have been familiar with the associations to both Jesus and magic that this figure carried in contemporaneous rabbinic culture. On the other hand, we have shown that several Christian amulets in Greek and Coptic include supposedly Jewish elements while employing anti-Jewish invective. In such cases, we think it highly unlikely that the creators of these artifacts recognized or valued these elements to enhance their spells with a "Jewish" flavor. 
Moreover, these artifacts indicate that the indigenization of a given Jewish element within Christian discourse in no way indicates that Christian practitioners and clients failed to distinguish between Christianity and Judaism or between Christians and Jews. In some cases, they drew precisely such distinctions, presumably highlighting this religious difference for ritual efficacy. But these practitioners drew the symbolic boundaries between Judaism and Christianity in ways that do not correspond in a one-to-one fashion with those of ancient heresiologists or modern scholars.

Based on the examples studied in this paper, we would venture a general methodological principle: absent indications to the contrary, scholars should begin from the supposition that the elements on a given artifact that belong to the shared magical culture of Jews and Christians no longer carried a Jewish valence, but rather were seen as indigenous features of the Christian tradition. In particular, scriptural citations from the Hebrew Bible (or, better, the Old Testament) and certain divine or angelic names, while perhaps having their historical origins in Jewish contexts, carried neither the taint of Jewishness nor a frisson of Jewish exoticism. In other words, the burden of proof ought to fall on the shoulders of scholars who would assume that Christian practitioners understood or utilized "Jewish" elements as Jewish. While taxonomies based on origins or idealized portraits of "Christianity," "Judaism," or even "Paganism" can be useful for charting changes in magical language over time, the blanket use of such taxonomies to organize "magical" artifacts distorts the various ways individual practitioners—as authors! — conceived of religious difference and, as a consequence, can lead to a fundamental misunderstanding of their ritual texts.

Once unfettered from the shackles of taxonomies based on origins rather than reception and use, amulets and spells can play an important role in reimagining how religious difference 
was configured in lived contexts during late antiquity. A careful reading of Patristic condemnations of magic reveals that many early Christians viewed the distinctions between Christians and non-Christians in ways that were in considerable tension with those who policed the boundaries of orthodoxy. ${ }^{81}$ And yet, this paper has also revealed that those Christians whose so-called magical practices may have made them targets of such efforts at marginalization could themselves deploy a familiar anti-Jewish rhetoric of subordination for their own ritual purposes. Even in those instances where we have observed Jewish and Christian ritual specialists working with a broadly shared repertoire of symbolic and material practices, we also found powerful hierarchies of religious difference at play. It would seem that, in the late antique Mediterranean at least, the very same conditions that promoted exchange across communal boundaries often went hand in hand with efforts at religious differentiation.

${ }^{81}$ See, for instance, H. F. Stander, “Amulets and the Church Fathers," Ekklesiastikos pharos 75 (1993) 5566. 